\title{
In the Name of Religion: Sexuality and Taboo in Salman Rushdie's Shalimar the Clown
}

\author{
Marcel Ebliylu Nyanchi \\ St. Peter Chanel Marist Major Seminary, Cameroon
}

\begin{abstract}
This paper examines socio-cultural and political interpretations of rape, love and sex in Shalimar the Clown to assess whether taboos on these practices in Kashmir are based on cultural and religious laws or are attempts by fundamentalists to re-colonize existing cultural and religious jurisprudences. I interrogate the orchestration of sexual violence through extremist Islamic doctrines like 'Sharia,' 'Hudood' and 'Zina' Ordinances, and 'Honour Killing' arguing that religious criminality transcends geopolitical and philosophical spaces. Through taboos on rape, love and sex, Rushdie satirizes the byzantine passion governing the quest for ecstasy in men, and its resultant effects of frigidity in women. Furthermore, the novel valorizes female sexual virility, because fundamentalist superstructures ironically groom sexually weak men, thereby impeding social conviviality. By satirizing taboos on domestic and social metamorphoses, Rushdie interrogates the place of fundamentalist ideology within contemporary world geopolitics. His valorisation of love and sex, suggest that they constitute immutable foundations on which societies should be founded.
\end{abstract}

Keywords: Religion, sexuality, violence, virility, taboos, geopolitics, fundamentalism.

"From the beginning, men used God to justify the unjustifiable."

The Satanic Verses (p.95)

The Indian subcontinent harbours major religions; Islam, Hinduism, Buddhism, Christianity etc and castes groups - Hindus, Muslims, Paravans, Sihks, Sunnis, Shi'its etc. The experiences of women in these groups and religions are different from those in other regions because they internalize patriarchy, segregate and tyrannize women in the domestic and public spheres. Since globalization reduces the world to a single entity, its tentacles are invading and diluting fundamentalist religious constructs. Salman Rushdie's experiences as an Anglo-Indian Muslim give him a composite knowledge of fundamentalist ideology. His Shalimar the Clown set in Kashmir, India and America depicts how interpretations of rape, sex and love affect notions of taboo in Islam, implying that Islam is experiencing schisms due to fundamentalism and terrorism. These schisms interrogate constructs like 'Sharia', 'Hudood, 'Zina' and "Purdah" which abound the novel as radical moments in religious transformation in Kashmir. Through intersections between knowledge, culture, globalization and sexual freedom, women are violated physically, psychologically and emotionally by socio-religious and historical alliances behind Indo-American invasion of Kashmir. The consequences are splinter fundamentalist groups that attempt to transform Kashmir into an 'Islamic' state.

Notably, Kashmiris respect women because The Koran emphasizes the principles of equity, equality, justice, freedom and liberation: "the believers are but a single brotherhood" (49:9). Ironically, sects collude with patriarchal traditions to use Islam to authenticate taboos on rape, love 
and sex, drawing from "Sharia laws," although controversies exist among Muslims whether or not these laws abound The Koran. Otto Jan Michiel (2008) examines Ali L. Khan's opinion that:

Sharia has been thoroughly confused in legal and common literature. For some Muslims, 'Sharia' consists of The Koran and 'Sunnah.' For others, it also includes both with classical 'figh. Most encyclopaedias define Sharia as law based upon The Koran, the Sunnah, and classical 'fiqh' derived from consensus (ijma) and analogy (qiyas)... The Koran and the 'Sunnah' constitute the immutable Basic Code, which should be kept separate from ever-evolving interpretive law (figh). This analytical separation between the Basic Code and 'fiqh' is necessary to dissipate confusion around the term 'Sharia.' (p.28)

To Otto, many people hardly distinguish between local norms, practices and tradition from religious laws. Adherence to "Sharia" tends to ascribe undesirable practices which overlook custom and culture. Although fundamentalist believe "Sharia" is God's law, they differ as to what exactly it entails. Anitta Kynsilehto (2008) argues that scholars challenging patriarchal readings of The Koran and the 'Hadiths' demonstrate that it is not the texts themselves, but their "interpretations that allow for patriarchal traditions to persist. The Koran, contains principles of gender equality and wider issues of social justice, thus laying grounds for challenging patriarchal traditions" (p.4). Consequently, Kashmiri Muslims hold different views of "Sharia," and that is why Shalimar the Clown mirrors the schisms and satirizes forms of violence committed on women.

\section{Sexual Violence and Taboos}

The publication of Shalimar the Clown in 2005, after the world trade centre bombings became another radical moment in Rushdie's writing after The Satanic Verses (1988). The novel satirises fundamentalist ideas on women in Kashmir which Rushdie (1992) justifies his attack on fundamentalism that:

Actually existing Islam has failed to create a free society anywhere on earth, and it wasn't about to let me, of all people in favour of one. Suddenly I was (metaphorically) among the people whose social attitudes I'd fought all my life - for example, their attitudes about women. (PP.436-37)

Justifiably, Kashmiri women are entrapped because terrorists hinge on sex for publicity in order to intimidate governments and the public. To them, just the name "woman" is derogatory because likening a man to a "woman" denigrates him to a weakling and a failure. The case of Colonel Hammirdev Suryavans Kachhwaha who receives a gift of two dozen lady's bangles on his birthday symbolizes failure as his father denigrates him saying:

'If a Rajput is still alive on his thirtieth birthday' [...]'we give him women's bangles to express our disappointment and surprise. Wear them until you prove they aren't deserved.' 'By dying, you,' his son sought clarification. 'To win favour in your eyes I have to get myself killed.' (p.95)

Rajpur folklore enjoins warriors to die before the age of thirty. By not dying in war, the Colonel becomes a "woman" and a failure in Rajpur mythology. Similarly, girls become sources of frustration for fathers who lose the respect to articulate in society. The case of Max Ophuls is peculiar because despite his daughter's (Kashmira) attempts to please Ophuls with pet names like "Max", "Maxine" and "Maxie," he does not understand that she is "begging him to stop mourning the male child he'd never had, to give up that old-fashioned sadness which he carried everywhere he went and which both wounded and offended her" (p.14). Despite Ophuls' wealth, he is unfulfilled because he feels 
the weight of his unborn son sitting up there jeering at his failure. Unlike Ophuls, some parents sell or kill girls which intensified after Indira Gandhi's assassination as Rushdie (2003) opines:

The murder of children is something of an Indian specialty. The routine daily killings of unwanted girl babies, the massacre of innocents in Nellie, Assam, in the 1980s, and the Sikh children in Delhi during the horrifying reprisal murders that followed Mrs. Gandhi's assassination bears witness to our particular gift, always most dazzlingly in evidence at times of religious unrest, for dousing our children in kerosene and setting them alight, or cutting their throats, or smothering them, or just clubbing them to death with a good strong length of wood. (p.344)

After Indira Gandhi's assassination in 1984, angry Hindus invaded, destroyed and murdered Sikh women and girls in the name of a retributive religion.

Also, sexual violence is manifested through the activities of the Indian army and the Lashkare-Pak (Lep) terrorist group operating in Kashmir. The narrator satirizes the trauma on women thus:

The fanatics kill our gens and the army shames our ladies [...]. Meanwhile the army used sexual assault to demoralize the population. In Kunan Poshpora, twenty-three women had been raped by soldiers at gunpoint. Systematic violation of young girls by entire Indian army units was becoming commonplace, the girls taken to army camps, naked, and strung up from trees, their breasts cut with knives. (pp.361-62)

Sexual violation during wars has become culturally tolerated as a "demoralization of the population through the violation of its women" (p. 291). Such genocidal drive of the LeP group and the Indian Army is satirized by Rushdie especially their brutal and unremitting campaign against Kashmiri women registering over 200,000 victims. Indian soldiers systematically rape Kashmiri women because of the "Zina Ordinances" under "Sharia" law which President Zia-ul-Haq introduced in Pakistan in 1979. According to Brendon Nicholls (2007), the Indian army and terrorists rely on the "Hudood" and "Zina" Ordinances to rape and torture women because:

The legal interpretation of rape within the second and third of the ordinances, the 'Zina Ordinance, means that the rape victim's testimony may amount to prima facie evidence of her indulgence in illicit fornication, as might any pregnancy resulting from the rape, while the perpetrator's denial, or even the complete failure to mount a legal defense, might mean that he avoids incrimination altogether. Compounding the difficulty in prosecuting the rapist are discrepancies in the weighting of evidence. Women's testimonies carry only half the weight of a man's. Furthermore, the eyewitness evidence of four Muslim males is required to be implemented. (p.117)

The 'Hudood' and 'Zina' Ordinances victimize raped women because hardly would they find four Muslim males to corroborate their accusations. When Zoon Misri is raped by the Gegroo brothers who remain unpunished due to lack of four eye witnesses, Misri becomes ostracized and "no man ever came to ask for her hand in marriage. That was how things were. Nobody could defend it but nobody could change it either" (p.129). Ironically, 'Sharia' courts prioritize oral testimonies from male witnesses and refuses forensic evidence, women's testimonies constitute only half the weight of men's. Since Misri cannot produce four eye witnesses, she commits suicide. In cases where rape results to pregnancy, the girl and her unborn child are ostracized for shaming and dishonouring her family and society. Amina Yaquin (2007) examines Rushdie's reaction to rape, the 'honour' and 'shame' phenomenon in India and Pakistan arguing that: 
The culture of rape that exists in India and Pakistan arises from profound social anomalies, its origins lying in the unchanging harshness of a moral code based on the concepts of honour and shame. Thanks to that code's ruthlessness, raped women will go on hanging themselves in the woods and walking into rivers to drown themselves. (p.68)

'Zina Ordinances' disregard raped women and this contradicts Koranic teachings that: "the Believers, men and women, are protectors one of another: they enjoin what is just and forbid what is evil" (9:71). That's why the Indian subcontinent is rated highest in female suicide with sources pointing to the notions of 'honour' and 'shame' encouraged by fundamentalists and terrorists.

Violence on women is also manifested through the dress and behavioural codes in Kashmir. Rushdie satirizes "Sharia" laws which forbid men and women from sitting together or closely. In Shalimar the Clown, the Lashkar-e-Pak or the Army of the Pure (LeP) enforces the dress and interaction code. Women's distaste for the code makes Firdaus to ask:

How can a woman's face be the enemy of Islam? She asked angrily. [...] For these idiots its all about sex, 'maej', excuse me. They think it is a scientific fact that a woman's hair emits rays that arouse men to deeds of sexual depravity. They think that if a woman's bare legs rub together, even under a floor-length robe, the friction of her thighs will generate sexual heat which will be transmitted through her eyes into the eyes of men and will inflame them in an unholy way [...]. So, because men are animals, according to them, women must pay. (p.301)

The dress code checks women who expose parts of their bodies and the LeP group's presence in Shirmal is bent on retribution. Drawing their inspiration from the Taliban in Afghanistan, the LeP group's pogroms are seen as:

Women teachers were doused with acid for failing to adhere to the Islamic dress code [...]. Men and women were not to sit together and watch television anymore. That was a licentious practice. Hindus were not to sit among Muslims. And of course, all women must instantly put on the veil. (p.277)

They torture women who object to wearing burqas like Bombur Yamabarzal who considers it an alien type of Islam. These retributive killings by the LeP push Sam Harris (2004) to conclude that "Islam, more than any other religion human beings have devised, has all the makings of a thoroughgoing cult of death" (p.123). The veils encouraged by the LeP constitute "purdah," whose etymology is Persian, meaning "veil" or "curtain" used for separating men and women in public and private spheres. M.S Joy (2006) emphasizes that "purdah" positively maintains "privacy and purity from prying eyes. Negatively, 'purdah' is a form of social restraint through which the individuality of the woman is erased by making her anonymous behind a veil and free interaction with the opposite sex is prevented" (p.12). Since 'purdah' imposes seclusion, Marnia Lazreg (2009) discusses its effects on women:

The women wearing black veils, socks, and gloves suffer even more, as the black colour absorbs the heat of the sun instead of reflecting it. The Afghan burqa which covers the face with its grid like woven pane, and the niqab, which leaves only a slit for the eyes, are equally inconvenient in hot weather, in addition to being difficult to manage: the long dress usually bunches up against and between the legs, preventing a woman from taking long steps or running. (p.104)

The veil perpetuates gender inequality, thereby instilling an inchoate sense of insignificance in women as social beings. To Lazreg (2009), women who accept the 'hijab' tell their male colleagues "I respect your deep-seated desire to see me covered" (ibid). It's also an expression of inferiority to 
men, despite their competence and skills. Rushdie satirizes this "moral code" because the subcontinent is evolving beyond the confines of cultural exclusivity. Furthermore, The Koran does not prohibit women from working, encouraging men to treat their women well and be kind to them as partners and committed helpers. Married women should seek employment although patriarchal societies argue that a woman's role as a wife and mother should have priority because "God has made for you spouses from among yourselves and through them has given you children and grandchildren and provided you of the good things" (16:72). Consequently, "purdah" restrains free movement which could make women liberal and likely to question religious orthodoxies in a world organized on the principles of merit, competence and equality. Shalimar the Clown becomes Rushdie's postcolonial indictment of such religious shift that imposes inhumane punishments for crimes that curtail and violate women's rights.

\section{Love, Marriage and Taboo}

Through marital relationships, I argue that patriarchal ideology re-colonizes women's "drives" towards heterosexual intercourse as Teenage dating is prohibited because a bride's virginity honours her parents. Fundamentalists' recourse to Koranic injunction that "the fornicatress and the fornicator, flog each of them with a hundred stripes. Let not pity withhold you in their case, in a punishment prescribed by God, if you believe in God and the Last Day. (24:2) becomes a yardstick that checks youths. When Boonyi stubbornly chooses Shalimar as husband, she becomes a focal point and Pachigamis are overwhelmed because she initiates the love contact which should be a male prerogative. That's why when they are caught fornicating by Gopinath, he threatens to tell tribal elders, saying:

The panchayat is meeting at this moment in emergency session to consider the evidence I have laid before it. Said Gopinath. The sarpanch, your father and the others will soon decide your fate. You are disgraced, of course, your face is blackened and your good name is dirt, and that is your own doing; but I have informed them that I am prepared to restore your honour by taking you as my wife. (pp.107-108)

Ironically, Gopinath's blackmail fails because the elders instead marry the youngsters, Boonyi and Shalimar, as a means of circumventing Koranic punishments and also to foster Hindu-Muslim cohesion. Abdullah invocates "Kashmiriyat" or Kashmiriness because "at the heart of Kashmiri culture there was a common bond that transcended all differences... "We are all brothers and sisters here" (p.110). He acknowledges that both Hindu and Muslim customs will be observed. Ironically, Boonyi later abandons Shalimar because she fears purdah's constrains, the types Ali Kecia (2010) examines through spousal relationships saying:

A wife's main duties to her husband were to obey him and be sexually available. In exchange, he fed, clothed, and housed her... In fact, their central notion about marriage was that the marriage contract granted a husband, in exchange for payment of dower, a form of authority or dominion over his wife's sexual capacity. (p.6)

The wife becomes a subaltern in Kashmir where arranged marriages are analogized to slavery. Rushdie satirizes female subjugation because "even the Indian army could not prevent families from arranging marriages" (p.118). Understanding that Shalimar "was just a clown, and his love led nowhere, would change nothing, would not take her where it was her destiny to go" (p.190), Boonyi elopes with Max Ophuls, U.S. Ambassador, who falls for her beauty. Arguably, Boonyi's decision is inspired by what Kecia (2010) calls "Maliki position" wherein: 
A husband not yet capable of intercourse need not maintain a grown wife, reflects a different legal principle that supersedes the standard rule about the wife's availability. It is not so much that the rules are incompatible as that the jurists draw on different principles in order to make their rulings. (p.95)

Boonyi defies Shalimar and tradition and elopes with Ophuls whose status transcends traditional and religious laws. Religiously, such adulterous act tantamounts to stoning to death as Paul Kurtz, Austin Dacey and Tom Flynn (2004) contend that according to the "Hadith," stoning to death is the "penalty for married men and women who commit adultery" (p.19). But, certain conditions related to the culprits must be met because religious judges cannot enforce stoning without the "confession of the person, or four male eyewitnesses who each saw the act being committed" (ibid). Though the "Hadiths" authorize punishments, Islamic societies are divided over their implementation.

Boonyi understands that divorce laws vary substantially between sects, schools and cultures in Pachigam and a marriage can easily be terminated by the husband in the "talaq" process, or by the wife seeking divorce through "khul." Men can unilaterally divorce under classical "Sharia" but families refuse to welcome fleeing wives. Thus why after departure, Shalimar's family declares Boonyi dead and mourns her religiously. Returning from the failed love spree, Boonyi becomes a ghost and no one, except Misri (the rapped and outcast friend) tells her that:

They killed you, she said. After what you did. They said you were dead to them and they announced your death and they made us all swear an oath. They went to the authorities and filled out a form and got it signed and stamped and so you are dead, and you cannot return. You have been mourned properly for forty days with all correct religious and social observances and so of course, you cannot just pop up again. You are a dead person. It's official. (p.223)

Though Islam authorizes women to request divorce, fundamentalists adjudicate that only men have the right to divorce wives, reason why Pachigami authorities quickly issue Boonyi's death certificate to Shalimar who threatens to "cut off her lying head, and if she had any bastard offspring with that sex-crazed American, he would show them no mercy, he would cut off their heads as well" (p.236). Her banishment to the forest facilitates Shalimar's revenge, thereby authenticating the death certificate and preserving the "honour" of his family as:

He came on foot, holding a knife [...]. She stepped out of her hut to greet him [...]. Everyone is dead, she said, my father's dead, and yours, and I think maybe you're dead too, so why should I want to live? [...] he moved toward her. He held it in his hands. (p.318)

The fact that Shalimar murders Boonyi and is not punished means Pachigami culture enjoins 'honour' killings. Shalimar later travels and America and murders Max Ophuls at Kashmira's doorstep. Nathan Gardels (2006) assesses Rushdie's explanation for this jihadist violence and concludes that such terrorism emanates from a dishonored manhood:

The character Shalimar picks up the gun not just because his heart gets broken, but because his pride and honour get broken by losing the woman he loves to a worldly man of greater consequence and power. That is what leads him down the path to slashing an American ambassador's throat. (p.7)

Shalimar's killing spree reflects what Akbar Noor Akbar Khalil and Ahmed Sheikh Mushood (2010) argue that parents kill their children and husbands kill their wives to maintain social recognition with perpetrators hardly punished by authorities. When a "father, brother or husband kills his wife, sister or daughter, they sit together and resolve the case before it goes to the police for investigation, or 
even if it goes to the police later on, the men have the power to withdraw the case" (p.37). Ironically, state institutions and the judiciary deal with crimes against women with extraordinary leniency, thereby, pardoning murderers in the name of "honour" to kill without punishment.

Contrarily, women who cannot divorce or quit their husbands endure the challenges that come with marriage like Firdaus who is bound to love Abdullah, a sexually weak husband and:

She hadn't minded, or had thought herself not to mind, that he had never pampered her, never remembered her birthday, never brought her a bunch of wildflowers plucked by his own hand. She had learned to accept the solitude of her marital bed, had resigned herself to a life time of sleeping beside a man whose most prolonged and enthusiastic sexual performance had been less than two minutes in duration. (p.245)

Firdaus sacrifices sexual pleasure for a home for their children because Pachigami patriarchs consider sex only as a baby-making process, thus branding sexually vigorous women as prostitutes, and stifling women's interest in sex for pleasure. Arguably, Pachigami women need two types of liberation; liberation from the oppression of men and liberation from sexual taboos that prohibit orgasm which communicates emotionally. According to Simone de Beauvoir (1974), such women reach menopause without experiencing orgasm which articulates emotional slavery since:

Many women become mothers and grandmothers without ever having experienced the orgasm or even any sex excitement at all [...] there are many wives who report that they consider their coital frequencies already too high and wish that their husbands did not desire intercourse so often [...]. But as we have seen, woman's erotic capabilities are almost unlimited. (pp.466-67)

Therefore, patriarchs become sexually weak because of foreplay and secondly, because "Sharia laws" forbid the touching of sensitive spots on women's bodies. Such orthodoxies are satirized by Rushdie in The Satanic Verses when Gibreel reveals that:

It was as if no aspect of human existence was to be left unregulated, free. The revelation told the faithful how much to eat, how deeply they should sleep, and which sexual positions had received divine sanction, so that they learned that sodomy and the missionary position were approved of by the archangel, whereas the forbidden postures included all those in which the female was on top [...] and earmarked the parts of the body which could not be scratched no matter how unbearably they might itch. (p.364)

Women become sex tools for men regardless of their own feelings, causing psychological violence. Such acts contradict The Koran which says "Your wives are a garment to you and you are a garment to them" (2:188), suggesting that marriage provides warmth, comfort, protection and acquiring offsprings. This explicitly states that both men and women are entitled to sexual gratification in marriage. Failure to provide these is ground for divorce which can be initiated by either parties because sex transcends procreational values and strengthens marital bonds. Shalimar the Clown therefore indicts Pachigami culture which inhibits women's interest in sex, making their lives to revolve around sexually weak men.

\section{Re-negotiating Sexual Taboos}

In order to eradicate religious and sex taboos, Kashmiris require new habits, policies and institutions that will address women's emotional and domestic problems. Rushdie's crusade for social justice 
subverts religious taboos on love by using Boonyi Kaul and Shalimar to celebrate her courage. This sexual relationship educates and promotes trans-religious and cultural marriages as Abdullah announces:

We are all brothers and sisters. There is no Hindu-Muslim issue. Two Kashmiri - two Pachigami - youngsters wish to marry, that's all. A love match is acceptable to both families and so a marriage there will be; both Hindu and Muslim customs will be observed [...]. To defend their love is to defend what is finest in ourselves. (p.110)

Sex therefore bridges inter-racial, religious and caste barriers, creating a forum for Hindu-Muslim cohesion. This cross-religious kinship through marriage is embedded in 'Kashmiriyat,' (Kashmiriness), a national romance that bridges ethnic and religious differences and creates a syncretic nation. Thus 'Kashmiriyat,' becomes a consensus as:

The love of Boonyi and Shalimar the clown had been defended by the whole of Pachigami, had been worth defending, as a symbol of the victory of the human over the inhuman, [...] for the first time in his life, the idea that human beings were essentially good, that if men could be helped to strip away imperfections their ideal selves would be revealed, shinning in the light, for all to see. (pp.238-239)

Boonyi's empowerment aligns with liberal feminist ideas that girls should now freely choose their husbands, thereby initiating a love contact which was previously a male prerogative. Confirming this view, Nancy Henley and Jo Freeman (1995), say:

The social rules say that all moves to greater intimacy are a male prerogative: it is boys who are supposed to call girls for dates, men who are supposed to propose marriage to women, and males who are supposed to initiate sexual activity with females. Females who make 'advances' are considered improper, forward, aggressive, brassy or otherwise 'unladylike.' By initiating intimacy, they have stepped out of their place and usurped a status prerogative. (pp.81-82)

Though patriarchs view female sexuality a taboo, branding women as prostitutes, Boonyi's action enlightens Kashmiri women who are reasserting their sexual space by subverting misogynistic constructs that make women receptive. Rushdie's women are sexually vigorous like Pamposh who confides her experiences to Firdaus:

In the matter of lovemaking Kashmiri women had never been shrinking violets, but what Pamposh confided to Firdaus made her ears burn. The sarpanch's wife understood that hidden away inside her friend was a personality so intensely sexual that it was a wonder the pandit was still able to get out of bed and walk around. (p.53)

Pamposh's sexual virility transcends misogynists who make love only to satisfy their short lived sexual urges. Though Pamposh and Boonyi lead their men in bed, they do not enjoy sexual pleasure the way de Beauvoir (1974) would have wanted because "it is the most perfect form of communion... and it is one of the greatest mysteries (p.228).

Rushdie satirizes male weakness by elevating women to trophies which soldiers fight and die to win like Colonel Kachhwaha who returns from battle to enjoy a beautiful woman:

Returning as a decorated war hero and enjoying the attentions of excited young women back home was not only permissible but actively encouraged. [...]. He began to dream of going home in triumph and having the pick of the women, the beautiful Rajput women of the kohlrimmed flashing eyes, the gorgeous Jodhpuri women waiting in their mirrored halls, opening wide their arms for their conquering local hero, dressed in clouds of organza and lace. (p.121) 
Unlike before when women were indiscriminately raped and tortured during wars, Rushdie's women are priceless trophies that inspire soldiers going to combat. Women's rejuvenation is a metaphor for Mother Nature who brings light and glory to these soldiers who are produced in their mother's bodies and recreated in the embraces of the woman in love. That is why during women's absence in Kashmir:

The men were going crazy. The men were masturbating like crazy and there were stories of crazy assaults on crazy local girls and when they were able to visit the crazy brothels of Srinagar, the crazy wooden houses shook with their crazy exploding lust. (p.98)

For soldiers who fall in battle, as female spirits (houris) convey their souls to paradise because The Koran promises them God mercies and "shall dwell with bashful virgins whom neither man nor jinnee will have touched before [...]. Virgins as fair as corals and rubies. Which of your Lord's blessings would you deny" (55:56-57). These verses encourage Muslim martyrdom and celebrate women's activities in Islamic paradise as Martha J. Reineke (1995) opines:

It is a beautiful place with fountains, pastures, cool pavilions, fruits, and 'Hur': lovely virgins. In the Garden, every male will have not only his wife but also seventy 'Hur.' The 'hur' are never sick, never menstruate, and are never bad-tempered. Each time a man returns to a 'hur,' he will find her virginity once again intact. (p.436)

Sexual gratification is Rushdie's advocacy in Shalimar the Clown which compliments what Michael S. Kimmel (1995) says:

Contemporary profeminist men are trying to integrate feminist ideas into their own lives. Sometimes they are even trying to talk with other men about $[\ldots]$ the changes that feminism will bring, contain significant and desirable changes for men as well and that the feminist vision of sexual equality and gender justice is both practically and morally a vision of a world in which we would want to live. (p.570)

Though Rushdie's feminist stance is widely condemned, his works radicalize Indian literature especially as his approaches to sexuality reveal that religious and cultural taboos on love, sex and marriage can easily be circumvented. By depicting female characters as sexually vigorous, Rushdie borrows from Helene Cixous (2004) who contends that "a woman without a body, dumb, blind can't possibly be a good fighter. She is reduced to being the servant of the militant male, his shadow" (p.296). Therefore, a woman without her sexuality is a woman without a body and cannot feel alive, which is patriarchy's problem on Kashmiri women.

\section{Conclusion}

The notion of sexuality in Shalimar the Clown articulates the postcolonial novel's interrogation of religious taboos that are fatally flawed and compromised. Female sexuality becomes a discourse of social change that encourages transformation against fundamentalism that subjugates women. Since fundamentalists justify tyranny and repression as divine retribution, this paper hinged on the historical and religious complexities that arise from the place of love, sex and marriage to interrogate taboos in Kashmir. Accordingly, Kashmiri politics should articulate a horizontal integration of socio-cultural and sexual liberation accompanied by new forms of regulation, backlash and conservatism. The novel therefore produces an incredible body of discourse on sexuality as a constructed and contested category in religious fundamentalism needing renegotiation, thereby offering a keen insight into a cross-cultural encounter. This will awaken women through a degree of religious unification and the spirit of Kashmiriness as a solution to the age old Hindu-Muslim divide. 
That's why his protagonist concludes that "the words Hindu and Muslim had no place in their story, he told himself. In the valley these words were merely descriptions, not divisions. The frontiers between the words, their hard edges, had grown smudged and blurred"' (p.57).

\section{Works Cited}

Beauvoir, Simone de. (1974). The Second Sex. Trans. and Ed. H. M. Parshley. New York: Vintage Books.

Cixous, Helene. (2004). "The Laugh of the Medusa:" Literature in the Modern World: Critical Essays and Documents. 2nd Edition. Ed. Dennis Walder. Oxford: OUP, 291- 300.

Fuller, Graham E. (2003). The Future of Political Islam. Palgrave: MacMillan.

Gardels, Nathan. (2006). "Salman Rushdie Interviewed”. New Perspectives Quarterly, (Winter), 7.

Harris, Sam. (2004). The End of Faith: Religion, Terror, and the Future of Reason. New York: W.W Norton and Company.

Henley, Nancy and Freeman, Jo. (1995). “The Sexual Politics of Interpersonal Behaviour." Women: A Feminist Perspective. $5^{\text {th }}$ Edition, Jo Freeman, ed. California: Mayfield Publishing Company, 79-91.

Joy, M.S. (2006). “The Veil as Metaphor for Repression in Salman Rushdie's Shame.” April 10, 2009. http://www.shvoong.com/books/114642-veil-metaphor-repression-salman-

Kecia Ali. (2010). Marriage and Slavery in Early Islam. New York, Harvard College.

Khalil, Akbar Noor and Mushood, Ahmed Sheikh. (2010). "Political Manipulation in Human Rights Violations: A Case of Honour Killings in Baluchistan, Pakistan." Pakistaniaat: A Journal of Pakistan Studies. Vol. 2, No. 2, 36-43.

Kimmel, S. Michael. (1995). "Misogynists, Masculinist, Mentors, and Male Supporters: Men's Response to Feminism." Women: A Feminist Perspective. 5th Edition, Jo Freeman, ed. California: Mayfield Publishing Company, 561-572.

Kurtz, Paul, Dacey Austin and Flynn, Tom. (2004). "Defaming Human Rights." Journal of the American Oriental Society. Vol. 45, No. 2, 17-23.

Kynsilehto. Anitta, ed. (2008). Islamic Feminism: Current Perspectives. Tampere: University of Tampere.

Lazreg, Marnia. (2009). Questioning the Veil: Open Letters to Muslim Women. Princeton: $\quad$ Princeton University Press.

Mahnaz, Afkhami, ed. (1995). Faith and Freedom: Women's Human Rights in the Muslim $\quad$ World. New York: Syracuse University Press.

Nicholls, Brendon. (2007). "Reading Pakistan in Salman Rushdie's Shame." The Cambridge Companion to Salman Rushdie. Ed. Abdulrazak Gurnah. Cambridge: Cambridge University Press, 109-23.

Otto, Jan Michiel. (2008). Sharia and National Law in Muslim Countries: Tensions and Opportunities for Dutch and EU Foreign Policy. Amsterdam: Amsterdam University Press.

Reineke, J. Martha. (1994). "Out of Order: A Critical Perspective on Women in Religion." Women: A Feminist Perspective. $5^{\text {th }}$ Edition, Jo Freeman, ed. California: Mayfield Publishing Company, 430-47.

Rushdie, Salman. (1988). The Satanic Verses. London: Viking Penguin.

_ _ (2005). Shalimar the Clown. New York: Random House. 
63 In the Name of Religion: Sexuality and Taboo in Salman Rushdie's Shalimar the Clown

_ _. (1992). Imaginary Homelands: Essays and Criticism 1981-1991. New York: $\quad$ Penguin Group.

_ _ (2003). Step Across This Line: Collected Nonfiction 1992-2002. New York: $\quad$ Random House.

The Koran. (1956). Translated by N. J. Dawood. New York: Penguin Books.

Yaqin, Amina. (2007). "Family and Gender in Rushdie's Writing." The Cambridge Companion to Salman Rushdie. Ed. Abdulrazak Gurnah. Cambridge: Cambridge University Press, 61-74.

Nyanchi Marcel Ebliylu holds a Ph.D in Commonwealth and postcolonial literary studies from the University of Yaoundé I, Cameroon. He lectures in the Department of English, Bilingual Studies, The Bilingual Training Unit, Performing Arts Section, Higher Institute of Translation and Interpretation and in St. Peter Chanel Marist Major Seminary. He has published in accredited journals nationally and internationally like East-West Cultural Passage and Subalternspeak: An International Journal of Postcolonial Studies in the domain of postcolonial literature. 